\title{
MODEL LINK AND MATCH DENGAN PENDEKATAN COMPETENCY BASED TRAINING PADA PEMBELAJARAN TATA GRAHA DI SEKOLAH MENENGAH KEJURUAN
}

\author{
Yoyoh Jubaedah, Neni Rohaeni dan Tati \\ Dosen PKK FPTK Universitas Pendidikan Indonesia \\ E-mail: yoju2010@yahoo.co.id
}

\begin{abstract}
ABSTRAK
Penelitian ini bertujuan mengembangkan model Link and Match dengan pendekatan Comptency based Training pada pembelajaran Tata Graha di SMK. Penelitian ini menggunakan metode deskriptif dengan pendekatan Research and Development. Studi pengembangan dilakukan dalam tiga tahap, yaitu: (1) Studi pendahuluan, (2) Pengembangan Model, dan (3) Uji validasi model. Pada tahap studi pendahuluan, meliputi kegiatan: (a) Studi literatur, (b) Identifikasi karakteristik kompetensi kerja keahlian Tata Graha, (c) Telaah pembelajaran Tata Graha di SMK. Tahap pengembangan model, meliputi kegiatan: (a) Merancang desain model link and match dengan pendekatan Competency based Training pada pembelajaran Tata Graha di SMK, (b) Mengembangkan program pembelajaran Housekeeping, (c) Ujicoba desain model. Pada tahap uji validasi model meliputi kegiatan: (a) Mengimplementasikan model, (b) Mengukur dampak penggunaan model terhadap capaian kompetensi peserta didik pada keahlian Tata Graha di SMK. Subjek penelitian terdiri dari peserta didik dan guru pengampu mata pelajaran Tata Graha di SMK. Teknik pengumpulan data dilakukan melalui studi dokumentasi, wawancara, observasi dan penilaian hasil belajar. Sesuai dengan tahapan penelitian, maka dihasilkan luaran sebagai berikut: (1) Model Link and Match dengan pendekatan Competency based Training pada pembelajaran Tata Graha di SMK, (2) Program pembelajaran Housekeeping di SMK kompetensi keahlian Akomodasi Perhotelan.
\end{abstract}

Kata Kunci: Link and Match, Competency based Training, Tata Graha, SMK

\section{ABSTRACT}

This study aims to develop a model of Link and Match with approach Competency based Training to Housekeeping in vocational schools. This research used descriptive method with Research and Development approach. The study of this development will be carried out in three phases, namely: (1) A preliminary study, (2) development model, and (3) model validation test. In the preliminary study phase, includes the following activities: (a) literature review, (b) Identify the characteristics of job competence Housekeeping skills, (c) Assessing learning in vocational Housekeeping. Stages of model development, including the following activities: (a) Model link and match the competency-based Training approach to learning Housekeeping in vocational schools, (b) develop learning program Housekeeping, (c) trial design model. At this stage of the model validation test includes the following activities: (a) Implement the model, (b) Measure the impact of the use of the model to the achievement of competence in the skills of learners in vocational Housekeeping. Research subjects consisted of students and teachers subjects in vocational Housekeeping. Data was collected through the study of documentation, interviews, observation and assessment of learning outcomes. In accordance with the stages of research, it produced the following outcomes: (1) Model Link and Match with competency-based training approach to learning Housekeeping in vocational schools, (2) Learning program Housekeeping in vocational competencies Housekeeping.

Keywords: Link and Match, Competency-based Training, Housekeeping, Vocational School (SMK)

\section{PENDAHULUAN}

Latar Belakang Masalah; Sekolah Menengah Kejuruan (SMK) sebagai lembaga pendidikan yang mengembangkan bidang vokasional di Indonesia memegang peranan penting dalam meningkatkan sumber daya manusia (SDM). Peningkatan SDM ini lebih diorientasikan pada pengalaman belajar peserta didik, yaitu melalui pendidikan dan pelatihan dengan cara memberikan pengetahuan dan keterampilan kepada peserta didik yang dapat diterapkan pada dunia kerja, sehingga mampu bersaing secara kompetitif dalam dunia kerja.

Kenyataannya cukup kontradiktif; tidak sedikit lulusan SMK yang menjadi pengangguran, karena tidak memiliki 
kompetensi sesuai dengan kebutuhan dunia kerja.Kesenjanganinisejalandenganpendapat yang diungkapkan Suparno (2008:1), bahwa: "Kompetensi para pencari kerja belum Link and Match dengan industri". Lapangan kerja bagi lulusan SMK sebenarnya cukup banyak peluang yang dapat dimanfaatkan, apabila sekolah mampu mengakomodasi kompetensi-kompetensi yang dibutuhkan di dunia kerja. Tidak sedikit SMK yang masih belum link and match dengan dunia kerja di dalam memberikan pengalaman belajar kepada peserta didik, baik dari pemilihan bahan ajar, sumber belajar, kegiatan maupun peralatan praktikum yang digunakan.

Fenomena ini menunjukkan bahwa SMK sebagai satuan pendidikan belum optimal dalam menyiapkan peserta didik dan lulusannya untuk memiliki kompetensi sesuai tuntutan dunia kerja. Oleh karena itu, kebijakan link and match bagi SMK, telah memberikan penegasan terhadap perlunya keterkaitan yang nyata antara penyelenggaraan pendidikan dengan kebutuhan masyarakat terutama dunia usaha dan industri yang akan menjadi dunia kerja para lulusan. Kebijakan tersebut pada dasarnya merupakan sarana untuk membangun kemitraan dengan industri dalam mengembangkan program pendidikan dan pelatihan bidang keahlian yang diselenggarakan pada satuan pendidikan SMK.

Model kerja sama yang sudah dilaksanakan antara SMK dengan dunia kerja diantaranya penerapan pendekatan pelatihan berbasis kompetensi (Competency based Training) yang harus dioptimalkan dalam upaya menghilangkan jurang ketidak link and match-an antara dunia pendidikan dengan dunia kerja. Asumsi ini sejalan dengan pendapat Djojonegoro (Pakpahan, 2002:231), bahwa: "Kebijakan link and match berusaha menempatkan pendidikan menengah kejuruan sebagai sub sistem dari sistem pembangunan nasional dalam peran dan tugas pengembangan sumber daya manusia”.

Berdasarkan uraian latar belakang masalah di atas, maka perlu dilakukan penelitian berkaitan dengan Pengembangan Model Link and Match dengan pendekatan Competency based Training pada pembelajaran Tata Graha di SMK. Competency based Training adalah proses pembelajaran yang perencanaan, pelaksanaan dan penilaiannya mengacu kepada penguasaan kompetensi yang telah dirumuskan sebagai standar acuan pencapaian hasil belajar sesuai standar dunia kerja.

Rumusan Masalah; Dari uraian latar belakang masalah, maka masalah penelitian ini dirumuskan sebagai berikut: "Model Link and Match dengan pendekatan Competency based Training yang bagaimana yang sesuai diterapkan pada pembelajaran Tata Graha di SMK?"

Tujuan Penelitian; Tujuan umum dari penelitian ini adalah untuk mengembangkan model Link and Match dengan pendekatan Competency based Training pada pembelajaran Tata Graha di SMK. Dari tujuan umum ini, maka dirumuskan tujuan khusus sebagai berikut: (a) Menganalisis literatur dan studi lapangan berkaitan dengan pembelajaran Tata Graha di SMK; (b) Mengidentifikasi karakteristik kompetensi kerja keahlian Tata Graha; (c) Merancang desain model link and match dengan pendekatan Competency based Training pada pembelajaran Tata Graha di SMK; (d) Mengembangkan program pembelajaran kompetensi keahlian Housekeeping di SMK; dan (e) Melakukan ujicoba desain model link and match dengan pendekatan Competency based Training pada pembelajaran Tata Graha di SMK.

Kajian pustaka dalam penelitian ini yaitu; pembelajaran yang dilaksanakan di SMK berorientasi pada dunia kerja, karena untuk menghasikan lulusan yang memiliki kompetensi kerja sesuai KKNI dan relevan dengan dunia usaha dan dunia industri. 
Pembelajaran tersebut diantaranya melalui penerapan pendakatan Competency based Training pada pembelajaran kehlian produktif.

Competency based Training (Pelatihan berbasis kompetensi) merupakan proses pengajaran yang perencanaan, pelaksanaan dan penilaiannya mengacu kepada penguasaan kompetensi peserta didik. Tujuan dari pendekatan ini adalah agar kegiatan yang dilakukan dalam proses pengajaran benar-benar mengacu dan mengarahkan peserta didik untuk mencapai penguasaan kompetensi yang telah diprogramkan bersama-sama dengan dunia usaha dan dunia industri.

Dengan pendekatan pelatihan berbasis kompetensi ini, pembelajaran pada intinya berisi seperangkat kompetensi yang perlu dimiliki peserta didik melalui proses kegiatan pembelajaran yang memiliki ciri sebagai berikut:(1) Kegiatan pembelajaran adalah penguasaan kompetensi oleh peserta didik; (2) Proses pembelajaran harus memiliki kesepadanan degan kondisi dimana kompetensi tersebut akan digunakan; (3) Aktivitas pembelajaran bersifat perseorangan (indvidualized instruction), antara satu peserta didik dengan peserta didik lainnya tidak ada ketergantungan; dan (4) Harus tersedia program pengayaan (enrichment) bagi peserta didik yang lebih cepat dan program perbaikan (remedial) bagi peserta didik yang lebih lamban.

Menguraikan kemampuan pekerja yang kompeten dalam sebuah pekerjaan mencakup mengidentifikasi dan mendaftarkan kinerjakinerja yang seharusnya ditampilkan pekerja kompeten dalam pekerjaan tertentu. Proses ini disebut juga "occuoational analysis" (analisis tugas-tugas pekerjaan). Dalam menganalisis tugas-tugas pekerjaan tersebut dapat mengkaji bagan tentang hubungan antara kompetensi kerja, program pelatihan, dan kompetensi lulusan yang dirujuk dari Blank, W.E. (1982), sebagai berikut.

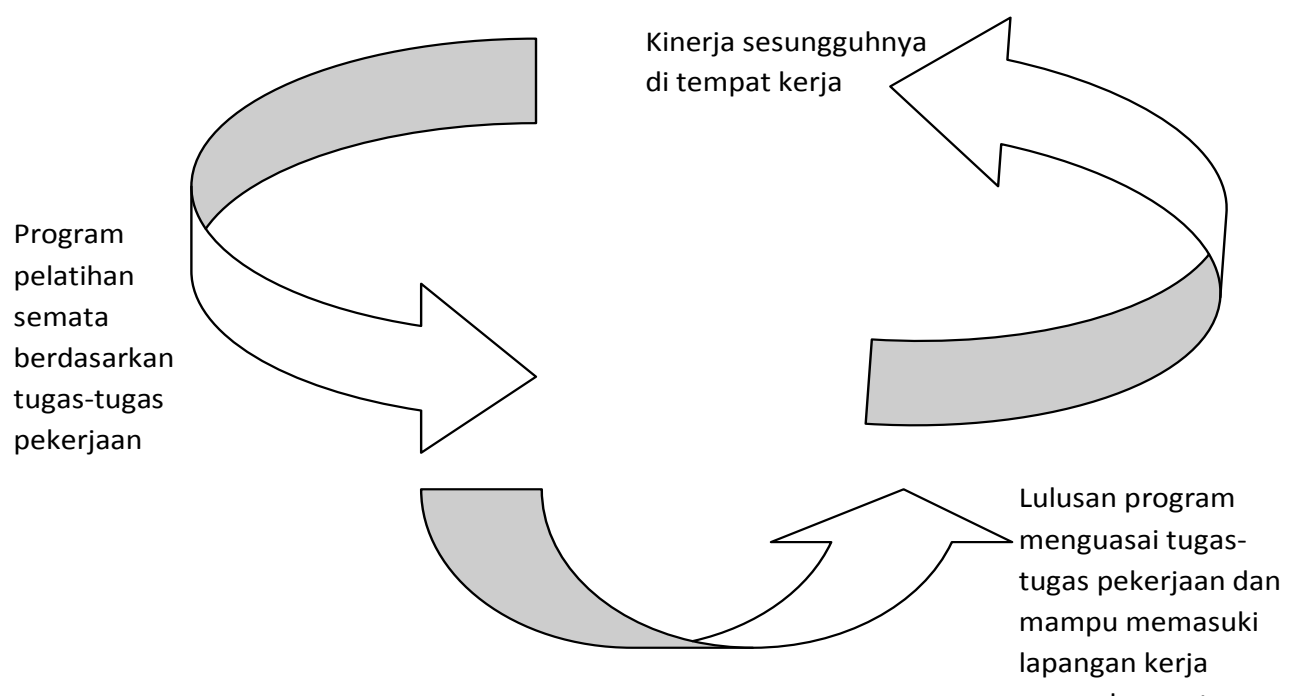

Pendekatan pembelajaran ini menekankan penguasaan kompetensi sesuai standar yang ditentukan, melalui kegiatan pembelajaran yang dirancang dan dilaksanakan secara terstruktur serta berfokus pada peserta didik (learner focused) melalui penyelesaian tugas/ kompetensi (task focused) secara bertahap.
Oleh karena itu, dalam penyelenggaraan pembelajaran dengan pendekatan pelatihan berbasis kompetensi harus memenuhi persyaratan sebagai berikut: (a) Kurikulum harus dikembangkan mengacu kepada standar kompetensi yang ditetapkan oleh industri/asosiasi profesi, dan memuat isi 
yang menunjang pencapaian kompetensi; (b) Modul/bahan ajar harus dikembangkan berdasarkan kurikulum dan standar kompetensi, serta mampu memberikan kesempatan kepada peserta didik untuk mengikuti program sesuai dengan tingkat kecepatan yang dimilikinya; (c) Guru atau instruktur harus memiliki kompetensi sesuai dengan bidangnya; (d) Peserta didik, telah memiliki kompetensi sesuai dengan bidangnya; (e) Kegiatan diklat diorganisasi secara tepat agar dapat dilaksanakan secara fleksibel dan memberikan perlakuan secara adil kepada peserta didik sesuai dengan potensi yang dimilikinya; (f) Fasilitas harus memadai untuk seluruh peserta didik, baik dari sisi jenis, jumlah dan kualitas; (g) Manajemen institusi perlu dikembangkan sesuai dengan semangat pembaharuan; dan (h) Biaya operasional diklat, memadai sesuai kebutuhan operasional dalam pencapaian kompetensi peserta didik.

Pembelajaran dengan pendekatan berbasis kompetensi, dalam pelaksanaannya tidak hanya menekankan pada pengetahuan saja tetapi juga menekankan kepada proses maupun sikap ilmiahnya. Melalui tugas dan kinerja diharapkan mampu melakukan penalaran ilmiah dalam arti berpikir secara efektif dalam menyelesaikan masalahmasalah yang dihadapi.

\section{METODE PENELITIAN}

\section{Pendekatan Penelitian}

Pendekatan penelitian yang digunakan adalah Penelitian dan pengembangan (Research and Development). Research and Development dalam penelitian ini meliputi tahapan: mengacu pada langkahlangkah yang dikembangkan Sukmadinata (2005:184), yaitu: (1) Studi Pendahuluan, (2) Pengembangan Model, dan (3) Uji Validasi Model.

\section{Lokasi dan Subjek Penelitian}

Penelitian dilakukan di SMK Negeri Kompetensi Keahlian Akomodasi Perhotelan di Kota Bandung, dengan subjek penelitian terdiri dari peserta didik dan guru pengampu mata pelajaran produktif keahlian Tata Graha.

\section{Teknik Pengumpulan Data}

Pengumpulan data penelitian dikelompokkan dalam tiga tahap, yaitu: (a) Studi Pendahuluan; Pada studi pendahuluan digunakan teknik wawancara, observasi dan studi dokumentasi yang ditunjang dengan kajian literatur; (b) Pengembangan Model; Pada tahap pengembangan model, ada dua langkah yang berkaitan dengan teknik pengumpulan data, yaitu ujicoba terbatas dan ujicoba lebih luas. Pada ujicoba terbatas dan ujicoba lebih luas ini menggunakan teknik pengumpulan data berupa pedoman observasi; (c) Uji Validasi Model; Pada uji validasi model, dilakukan kepada pihak internal (guru) dan eksternal (praktisi) untuk menghasilkan model link and match yang teruji baik pada tingkat internal maupun eksternal, sehingga diketahui dampak dari penggunaan model terhadap tingkat capaian kompetensi peserta didik pada standar kompetensi Housekeeping di SMK.

\section{Teknik Analisis Data}

Teknik analisis data yang dilakukan mencakup analisis data pada tahap studi pendahuluan, pengembangan model dan validasi model.

Pada tahap studi pendahuluan, temuan tentang model sebagai hasil pengembangan yang dideskripsikan dalam bentuk sajian data naratif, kemudian dianalisis secara kualitatif.

Pada tahap pengembangan terdiri dari beberapa pendekatan di dalam menganalisis data temuan penelitian, yaitu: 1) Pelaksanaan dan hasil pengembangan desain model dideskripsikan dalam bentuk sajian data naratif, yang kemudian dianalisis secara kualitatif. 2) Pada uji coba model, hasil uji coba penerapan desain model dianalisis 
dengan pendekatan kuantitatif.

Pada tahap validasi model, dianalisis menggunakan pendekatan kuantitatif terhadap program yang dikembangkan untuk melihat dampak dari model yang dikembangkan terhadap tingkat capaian kompetensi peserta didik pada standar kompetensi Housekeeping di SMK program keahlian Akomodasi Perhotelan.

\section{HASIL PENELITIAN DAN PEMBAHASAN}

Model Link and Match sebagai model pembelajaran yang dihasilkan melalui Research and Development, meliputi perencanaan pembelajaran, pelaksanaan pembelajaran dan penilaian hasil belajar (uji kompetensi), pada standar kompetensi "Housekeeping" di SMK Kompetensi Keahlian Akomodasi Perhotelan.

Dari berbagai temuan dalam pengembangan model Link and Match dengan pendekatan Competency Based Training yang diterapkan pada pembelajaran standar kompetensi Housekeeping di SMK Kompetensi Keahlian Akomodasi Perhotelan telah teruji efektif di dalam peningkatan capaian kompetensi peserta didik. Kondisi ini tertampilkan dari hasil uji coba terbatas dan uji coba lebih luas yang menunjukkan bahwa, tingkat capaian kompetensi peserta didik adanya peningkatan dari pelatihan pertama, kedua, ketiga hingga keempat. Dapat dimaknai bahwa kompetensi peserta didik dapat meningkat apabila pengalaman belajar mereka diprogram dan dikondisikan sesuai denga tuntutan standar industri, sehingga para peserta didik akan memperoleh pengalaman nyata dan capaian kompetensi yang optimal.

Peningkatan capaian kompetensi teruji dari Validasi model yang dilakukan melalui studi eksperimen dengan cara membandingkan capaian kompetensi antara kelas eksperimen dengan kelas kontrol. Melalui kegiatan validasi model ini diperoleh temuan sebagai berikut.

\begin{tabular}{|c|c|c|c|c|}
\hline \multirow{2}{*}{ Siswa } & \multicolumn{2}{|c|}{ Kelas Kelompok Eksperimen } & \multicolumn{2}{|c|}{ Kelas Kelompok Kontrol } \\
\hline & Skor Akhir & Keterangan & Skor Akhir & Keterangan \\
\hline 01 & 90 & Kompeten & 80 & Kompeten \\
\hline 02 & 90 & Kompeten & 75 & Kompeten \\
\hline 03 & 90 & Kompeten & 75 & Kompeten \\
\hline 04 & 90 & Kompeten & 80 & Kompeten \\
\hline 05 & 90 & Kompeten & 80 & Kompeten \\
\hline 06 & 90 & Kompeten & 75 & Kompeten \\
\hline 07 & 85 & Kompeten & 80 & Kompeten \\
\hline 08 & 90 & Kompeten & 80 & Kompeten \\
\hline 09 & 90 & Kompeten & 85 & Kompeten \\
\hline 10 & 90 & Kompeten & 85 & Kompeten \\
\hline 11 & 90 & Kompeten & 75 & Kompeten \\
\hline 12 & 90 & Kompeten & 85 & Kompeten \\
\hline 13 & 90 & Kompeten & 80 & Kompeten \\
\hline 14 & 90 & Kompeten & 80 & Kompeten \\
\hline 15 & 90 & Kompeten & 85 & Kompeten \\
\hline 16 & 90 & Kompeten & 85 & Kompeten \\
\hline 17 & 85 & Kompeten & 75 & Kompeten \\
\hline 18 & 90 & Kompeten & 80 & Kompeten \\
\hline 19 & 90 & Kompeten & 80 & Kompeten \\
\hline 20 & 85 & Kompeten & 85 & Kompeten \\
\hline 21 & 90 & Kompeten & 80 & Kompeten \\
\hline 22 & 90 & Kompeten & 75 & Kompeten \\
\hline 23 & 90 & Kompeten & 80 & Kompeten \\
\hline 24 & 90 & Kompeten & 75 & Kompeten \\
\hline
\end{tabular}




\begin{tabular}{|c|c|c|c|c|}
\hline 25 & 90 & Kompeten & 80 & Kompeten \\
\hline 26 & 90 & Kompeten & 80 & Kompeten \\
\hline 27 & 90 & Kompeten & 85 & Kompeten \\
\hline 28 & 90 & Kompeten & 75 & Kompeten \\
\hline 29 & 90 & Kompeten & 80 & Kompeten \\
\hline 30 & 90 & Kompeten & 80 & \\
\hline Rata-rata & 89,50 & & 79,83 & \\
\hline
\end{tabular}

Dari laporan hasil uji kompetensi di atas, dilakukan uji hipotesis menggunakan Levene's Test (Pedoman Analisis Data dengan SPSS, 2009). Uji t yang digunakan adalah uji $t$ dua sampel independent dengan asumsi kedua varian tidak sama, memberikan nilai $\mathrm{t}=10,91$ berada di luar daerah penerimaan dengan sig (2-tailed) $=0,000$ lebih kecil dari 0,05, maka $\mathrm{H}_{0}$ ditolak. Artinya, terdapat perbedaan rata-rata perolehan skor akhir antara kelas kelompok eksperimen dan kelas kelompok kontrol pada standar kompetensi Housekeeping. Dapat disimpulkan bahwa, penggunaan model Link and Match pada Pembelajaran Housekeeping di SMK Kompetensi Keahlian Akomodasi Perhotelan menunjukkan cukup efektif untuk capaian kompetensi peserta didik, sehinga model yang dikembangkan layak untuk diimplementasikan pada kompetensi yang setara atau serumpun di SMK yang lebih luas.

Model Link and Match dengan pendekatan Competency Based Training ini akan berhasil apabila perencanaan pembelajaran, pelaksanaan pembelajaran dan penilaian hasil belajar mengacu pada standar industri dan melibatkan kedua belah pihak, yaitu pihak internal dan eksternal. Program pembelajaran dikembangkan oleh guru pengampu sebagai pihak internal dan praktisi dari industri sebagai pihak eksternal, sehingg pengalaman belajar peserta didik di SMK akan Link and Match dengan dunia kerja. Simpulan ini sejalan dengan yang disarikan dari Blank, W.E. (1982) bahwa, program pelatihan yang efektif dalam menyampaikan pengajaran adalah: 1) menyebutkan dengan jelas tentang apa program itu dan seberapa baik peserta didik belajar, 2) memberikan kegiatan belajar yang berpusat pada peserta didik, 3) memungkinkan siswa mendapatkan waktu yang memadai untuk menguasai kompetensi secata tuntas.

Pendekatan Competency Based Training yang disarikan dari Blank, W.E. (1982) mengandung makna bahwa, pengembangan program pendidikan dan pelatihan jabatan atau pekerjaan yang efektif mulai dari merumuskan hasil belajar peserta didik (learning outcomes) yang dinyatakan secara jelas, dapat diamati dan diukur sampai kepada bagaimana mengevaluasi penampilan atau kinerja peserta didik setelah proses pembelajaran. Di samping itu ada penekanan pada "belajar" (learning) ketimbang "mengajar" (teaching) dalam setiap kegiatan peserta didik menyelesaikan tugas-tugas untuk mencapai kompetensi kerja yang telah ditentukan melalui paket-paket belajar yang dikembangkan dan dimediasi oleh guru secara hati-hati dan seksama agar peserta didik mencapai ketuntasan belajar.

Pandangan di atas sejalan pula dengan pendapat yang disarikan dari Sulivan (1995), bahwa dalam Competency Based Training, unit kemajuan adalah penguasaan pengetahuan dan keahlian tertentu yang berpusat pada peserta didik. Istilah-istilah utama yang digunakan dalam pelatihan berbasis kompetensi meliputi keahlian dan kompetensi. Keahlian merupakan suatu tugas atau kelompok tugas yang dilakukan pada suatu tingkat tertentu atau kemahiran yang seringkali menggunakan fungsi gerak. Kompetensi merupakan suatu keahlian yang dilakukan untuk standar tertentu dalam kondisi tertentu. Program pembelajaran yang 
dirancang dengan pendekatan Competency Based Training, menganut dua konsep dasar filosofis yaitu: 1) Pengertian kompetensi manusia (human competencies) adalah kemampuan untuk menunjukkan kinerja (unjuk kerja). Pengetahuan, sikap, dan nilai yang dimiliki tidak banyak bermanfaat tanpa menunjukkan kemampuan kerja yang terlihat dalam hasil belajar; dan 2) Filosofis belajar tuntas (mastery learning). Konsep ini meyakini bahwa kebanyakan orang akan belajar banyak jika disediakan pengajaran yang berkualitas dan menggunakan cukup waktu.

Pembelajaran berlangsung berdasarkan kondisi-kondisi tertentu yang didesain menurut kompetensi-kompetensi khusus yang telah ditetapkan sebelumnya. Seluruh kegiatan belajar mengajar bermuara pada pencapaian kompetensi peserta didik melalui pendekatan belajar tuntas (mastery leaning). Evaluasi dan penilaian hasil belajar diukur atas dasar seberapa jauh peserta didik telah mampu menampilkan kinerja yang menunjukkan pemahaman dan keterampilan yang didemonstrasikan dalam kerangka perilaku (behaviour) yang dirumuskan secara spesifik. Ketercapaian atau keberhasilan peserta didik untuk sebuah elemen behavioral dapat diukur melalui indikator kinerja.

Penilaian hasil belajar atau pengukuran capaian kompetensi sebagai temuan penelitian pengembangan model Link and Match dengan pendekatan Competency Based Training, masih perlu dikembangkannya model penilaian dan alat penilaian yang mengakomodasi tuntutan standar industri terkait dengan indikator-indikator kinerja yang harus diukur. Asumsi ini sejalan dengan pendapat yang disarikan dari Stiggins (1994) bahwa, target pencapaian hasil belajar yang dapat diraih dalam evaluasi kinerja meliputi aspek-aspek berikut ini: 1) knowledge, 2) reasoning, 3) skill, 4) product, dan 5) affect.

Merujuk pada pendapat para ahli yang mengembangkan Competency Based Training, dapat dimaknai bahwa pendekatan tersebut sangat tepat apabila diterapkan pada pembelajaran di Sekolah Menengah Kejuruan yang bertujuan untuk menghasilkan lulusan yang memiliki kemampuan kerja sesuai dengan tuntutan standar industri. Competency Based Training merupakan suatu pendekatan bagi pendidikan dan pelatihan kejuruan yang menekankan pada apa yang dapat dilakukan seseorang di tempat kerja sebagai suatu hasil penyelesaian suatu program pelatihan. Ciri utama Competency Based Training adalah keberhasilan setiap peserta didik dinilai dengan standar industri yang mengarah pada keterampilan dan kemampuan yang dibutuhkan untuk melakukan tugas tertentu.

\section{KESIMPULAN}

Dari seluruh kegiatan penelitian mengenai pengembangan model Link and Match dengan pendekatan Competency Based Training pada pembelajaran Tata Graha di SMK dapat disimpulkan sebagai berikut:

1. Model link and match dengan pendekatan Competency based Training pada pembelajaran Tata Graha di SMK meliputi perencanaan pembelajaran, pelaksanaan pembelajaran dan penilaian hasil belajar dikembangkan mengacu pada standar industri.

2. Program pembelajaran Tata Graha dirancang merujuk pada karakteristik Kurikulum Tingkat Satuan Pendidikan SMK Kompetensi Keahlian Akomodasi Perhotelan dan standar kompetensi kerja hotel.

3. Model link and match dengan pendekatan Competency based Training dapat meningkatkan capaian kompetensi peserta didik pada standar kompetensi Housekeeping di SMK Kompetensi Keahlian Akomodasi Perhotelan.

4. Optimalisasi Competency based Training 
di SMK melalui pengalaman belajar yang dikondisikan sesuai replika di industri dengan cara melibatkan pihak eksternal (industri) pada tahap perencanaan, implementasi dan evaluasi.

5. Model link and match dengan pendekatan Competency based Training pada pembelajaran Tata Graha di SMK teruji efektif di dalam peningkatan capaian kompetensi peserta didik pada standar kompetensi Housekeeping. Keterujian tersebut terlukiskan pada prestasi kelas eksperimen yang menunjukkan nilai capaian kompetesi lebih tinggi dibandingkan dengan kelas kontrol.

\section{DAFTAR PUSTAKA}

Blank, W.E. (1982). Handbook for Developing Competency Based Training. New Jersey : Prentice-Hall Inc.

Pakpahan, J. (2002). Perkembangan Pendidikan Menengah Kejuruan Pada Pelita VI. Jakarta: Departemen Pendidikan Nasional.

Stiggins, R.J. (1994). Student Centered Classroom Assessment. New York: Macmillan College Publishing Company.

Sukmadinata, N.S. (2005). Metode Penelitian Pendidikan. Bandung: PT Remaja Rosdakarya.

Suparno, Erman. (2008). Kompetensi, Jabatan Penghubung Dunia Pendidikan dan Industri. Terdapat di [On line] ht tp://www. Edubenchmark.com/ 